\title{
Repeated inoculations of Mycobacterium bovis Bacille Calmette-Guérin (BCG) are needed to induce a strong humoral immune response against antigens expressed by the bacteria
}

\author{
Monique C. da Silva ${ }^{1}$, Elena B. Lasunskaia ${ }^{1}$, Wilmar Dias da Silva ${ }^{2 \#}$ \\ ${ }^{1}$ Laboratory of Biology of Recognition, Universidade Estadual do Norte Fluminense, Campos, Rio de Janeiro, Brazil \\ ${ }^{2}$ Laboratory of Immunochemistry, Institute Butantan, São Paulo, Brazil; ${ }^{\#}$ Corresponding Author: wds@ butantan.gov.br
}

Received 18 April 2013; revised 16 May 2013; accepted 30 May 2013

Copyright (C) 2013 Monique C. da Silva et al. This is an open access article distributed under the Creative Commons Attribution License, which permits unrestricted use, distribution, and reproduction in any medium, provided the original work is properly cited.

\begin{abstract}
The cellular immune response elicited by $M y-$ cobacterium bovis Bacille Calmette-Guérin (BCG) has been carefully investigated, but the humoral immune response has been partially neglected. BALB/C mice were immunized with BCG strain used to immunize humans. Anti-BCG antibodies, as assayed by ELISA, began to appear in the sera after the third week of immunization and plateaued three weeks after the $8^{\text {th }}$ immunization. The total immunoglobulins (Igs) were purified by caprylic acid method from pooled serum collected after the $8^{\text {th }}$ immunization. Anti-BCG antigen antibodies were detected in the total Igs preparation as well as in $\lg G, \lg M, \lg A, \lg G_{1}$, $\lg G_{2 a}$, and $\lg G_{2 b}$, but not in the $\lg _{3}$. Distinct BCG proteins were recognized the IgGs in Western blot analysis. Opsonization of BCG bacilli by the purified Igs potentiated internalization of the bacteria by murine Raw 264.7 macrophages. The intracellular BCG elimination coincided with the induction of NO production, which was more pronounced in cells infected with opsonized BCG compared to those infected with the non-opsonized bacteria. Coincidently, the production of NO was also higher in macrophages infected with opsonized BCG (maximal NO production at $48 \mathrm{~h}$ of incubation). The obtained results demonstrate that repeated inocu-

\footnotetext{
"The results were used by Monique Camila da Silva to obtain her Masters Degree in Biosciences and Biotechnology from the Laboratory of Biology of Recognition, Universidade Estadual do Norte FluminenseDarcy Ribeiro, with a fellowship from "Coordenação de Aperfeiçoamento de Pessoal de Nível Superior,Brasília, Brasil” (CAPES).

The authors have no financial conflict of interest.
}

lations of BCG effectively activate the humoral immune response, justifying the use of BCG as a live recombinant vaccine vector to insert genes encoding virulence factors controlled by antibodies.

Keywords: Mycobacterium bovis; Bacille Calmette-Guérin; BCG; Antibodies; Opsonization; Bacterial Killing

\section{INTRODUCTION}

Bacille Calmette-Guérin (BCG) is an attenuated strain of Mycobacterium bovis first used to vaccinate children with a high risk of acquiring tuberculosis (TB) [1]. BCG has become the most widely used vaccine, reaching 3 billion vaccinated individuals [2]. A meta-analysis of individuals vaccinated with $\mathrm{BCG}$ indicates that the risk of acquiring active TB is reduced by approximately 50 percent [3]. Widely recovered epidemiological data suggest that the efficacy of the BCG vaccine depends on several associated factors, such as the immune state of the recipient [4], the intensity and frequency of the exposure to the mycobacteria prior to vaccination [5], and the recipient age $[6,7]$. Therefore, the capacity of BCG to induce an immune response is indirectly indicated. Reinforcing this capacity is the well-recognized ability of BCG to live and multiply in macrophage phagosomes, which facilitates the interaction between the BCG antigens and MHC class II molecules, resulting in the activation of a CD4+ Th1 cell immune response. The observed presence of lipoarabinomannan on the BCG outer cell surface and the ability of this complex molecule to act as an immune adjuvant may increase the potential immunogenicity of BCG [8]. This probable immunogenicity 
underlies the inclusion of mycobacteria into complete Freund's adjuvant to improve the immune response in experimental protocols [9].

The immune response induced by BCG is predominantly $\mathrm{T}$ cell-dependent [10]. The cellular immune response has been followed essentially by evaluating in parallel the activated $\mathrm{T}$ cell subtypes and the cytokine profile [11]. Studies addressing the T cell response have considered that antibodies play a minor role in the immune protection against tuberculosis. However, antibodies may facilitate mycobacterial elimination by increasing bacterial opsonization [12].

A direct investigation aimed to detect the eventual antibody production in response to $\mathrm{BCG}$ was performed by comparing the humoral immune responses induced by BCG strains grown in different culture media [13].

A recent analysis of the immunological response after oral re-vaccination with $M$. bovis BCG Moreau RDJ in adults who were intradermally immunized in infancy demonstrated an increase in the humoral immune response without tolerance, and a switch from IgG to IgA was detected [14].

Altogether, these data indicate that BCG immunization induces not only cellular immunity but also the humoral immune response. Immunization protocols that lead to high levels of antibody production in response to BCG should be established.

Recently, BCG vaccine strains began to be intensively investigated as vehicles to deliver heterologous antigens to induce both the humoral (mucosal and systemic) and cell-mediated immune responses $[15,16]$, reinforcing the interest in the induction of antibody production by BCG.

Here, we describe an immunization scheme based on repeated booster inoculations with the vaccine and the antibody profiles of prevalent anti-BCG immunoglobulin classes and subclasses induced in mice. Additionally, we evaluated the capacity of these antibodies to opsonize live BCG bacilli for phagocytosis and subsequent destruction within macrophage phagolysosomes. The results demonstrate that the attenuated M. bovis strain BCG is a potent immunogen, which induces a strong humoral response under hyperimmunization conditions, leading to the production of different classes and subclasses of specific immunoglobulins with opsonizing properties.

\section{MATERIALS AND METHODS}

\subsection{Animals}

BALB/c mice ( 8 weeks old, 18 - 22 g, 5 animals per group) were supplied by "Biotério Central da Universidade Estadual do Norte Fluminense-Darcy Ribeiro (UENF)" and maintained at the animal facility of the Laboratório de Biologia do Reconhecer, Centro de Biociências e Biotecnologia, UENF. All animals were cared for under ethical conditions according to International Welfare Recommendations [17,18]. The protocols used were approved by the Institutional Animal Care and Use Committee CBB/UENF, RJ, Brazil.

\subsection{Bacterial Strains, Growth Conditions and Whole Extracts}

All experiments were performed using the id-BCG Moreau Copenhagen strain (1978) currently utilized in the Brazilian TB immunization program. The BCG samples were supplied by the Institute Butantan, São Paulo, $\mathrm{SP}$, in lyophilized form at the concentration of $1.0 \mathrm{mg} / \mathrm{ml}$ $-1.0 \times 10^{5}$ bacilli $/ \mathrm{mL}$. Liquid cultures of BCG were grown in Middlebrook 7H9 media (MB7H9; Difco, MI, USA) supplemented with albumin-dextrose-catalase (ADC) (MB7H9/ADC) with gentle shaking at $37^{\circ} \mathrm{C}$. To determine the number of colony-forming units (CFU) in the bacterial suspensions, the culture samples were serially diluted and plated onto Middlebrook $7 \mathrm{H} 10$ agar plates supplemented with OADC (MB7H10/OADC). The plates were incubated for 3 weeks at $37^{\circ} \mathrm{C}$, and the $\mathrm{CFU}$ were counted.

To obtain whole cell lysates of BCG (BCG-WCL) samples of the BCG suspensions containing $1.0 \times 10^{6}$ bacilli $/ \mathrm{mL}$ were centrifuged at $4000 \mathrm{~g}$ at $4^{\circ} \mathrm{C}$ for $50 \mathrm{~min}$. The sediments were collected and homogenized in lysis buffer (Tris-HCl $10 \mathrm{mM}, \mathrm{NaCl} 10 \mathrm{mM}, 0.5 \%$ SDS, 25 $\mathrm{mM}$ EDTA) at $\mathrm{pH}$ 7.8. The bacilli were submitted to 12 alternating cycles of freezing in liquid $\mathrm{N}_{2}$ and thawing in a water bath at $37^{\circ} \mathrm{C}$. The disrupted bacilli were then sonicated $(50 \mathrm{~Hz}$ for $30 \mathrm{~min})$, the extracts were centrifuged at $4000 \mathrm{~g}$ for $15 \mathrm{~min}$, and the protein concentrations were determined.

\subsection{Mouse Immunizations}

For the immunizations, the BCG strain was grown in MB7H9 for 2 weeks until the late stationary phase $($ O.D. $600 \mathrm{~nm}=1.0)$. The bacteria were collected by centrifugation (4000 rpm at $4^{\circ} \mathrm{C}$ for $10 \mathrm{~min}$ ), washed twice and suspended in PBS to $10^{6} \mathrm{CFU} / \mathrm{mL}$. Each mouse was intradermally inoculated eight times with $2 \times 10^{5}$ bacilli, $0.1 \mathrm{mg}$ in $100 \mu \mathrm{L}$ PBS, with an interval of 3 weeks between the first and the second inoculations followed by 2 week intervals between the next six immunizations. Control groups of mice received $100 \mu \mathrm{L}$ PBS. Before the immunizations, pre-immune serum was collected. The presence of anti-BCG antibodies in the sera from immunized and control mice was analyzed by ELISA, and the BCG protein bands recognized by the serum were visualized by Western blotting.

\subsection{Purification of Anti-BCG Antibodies}

Blood was collected by venomous puncture from 
anesthetized mice. The blood samples were allowed clotting at room temperature for $1.0 \mathrm{~h}$ and kept for $16 \mathrm{~h}$ at $4^{\circ} \mathrm{C}$. The clotted blood was centrifuged at $2000 \mathrm{rpm}$ for $20 \mathrm{~min}$, the serum was withdrawn, diluted $1 / 3$ in $\mathrm{pH} 4.0$, $60 \mathrm{mM}$ acetate buffer, and the IgG immunoglobulins were purified by negative precipitation with caprilic acid [19]. The $\mathrm{pH}$ of the resulting purified IgG was adjusted to $\mathrm{pH} 7.2$, by adding $3 \mathrm{M}$ Tris solution. The IgG immunoglobulins, were further purified by adding ammonium sulfate, at $4^{\circ} \mathrm{C}-8^{\circ} \mathrm{C}$, until $45 \%$ saturation. The precipitated $\mathrm{IgG}$ was separated by centrifugation at $5000 \mathrm{~g}$, for $15 \mathrm{~min}$, dissolved in $0.15 \mathrm{M} \mathrm{NaCl}$ and dialyzed against PBS. Protein concentration of dialyzed IgG was determined by the bicinconic acid (BCA) method.

\subsection{Anti-BCG Antibody Quantification and Characterization}

Measurement of antibodies by ELISA. Samples of sera were collected before and after each immunization, and BCG-specific antibodies were evaluated by enzymelinked immunosorbent assay (ELISA). Briefly, microtiter plates were coated overnight at $4^{\circ} \mathrm{C}$ with $2 \mu \mathrm{g} / \mathrm{mL}$ of whole $\mathrm{BCG}$ extract diluted in carbonate buffer $(0.015 \mathrm{M}$ $\mathrm{Na}_{2} \mathrm{CO}_{3}, 0.035 \mathrm{M} \mathrm{NaHCO}_{3}$ ), pH 9.7. After washing, the plates were blocked with $100 \mu \mathrm{L}$ of $10 \%$ FBS in PBST for $2 \mathrm{~h}$ at room temperature. Aliquots of serial dilutions of murine sera or purified anti-BCG IgG diluted in PBS containing $10 \%$ FBS were added to the individual wells. After incubation for $1 \mathrm{~h}$ at $37^{\circ} \mathrm{C}$, the wells were washed five times with PBST, and $50 \mu \mathrm{L}$ of peroxidase-labeled isotype-specific secondary detection antibodies (rabbit anti-mouse $\mathrm{IgG}$ (total) or anti-mouse $\mathrm{IgG}_{1}, \mathrm{IgG}_{2 \mathrm{a}}, \mathrm{IgG}_{2 \mathrm{~b}}$, $\mathrm{IgG}_{3}$, IgA and IgM; Santa Cruz Biotechnology Inc., USA) diluted 1:2000 were added. The plates were incubated for an additional $1 \mathrm{~h}$ at $37^{\circ} \mathrm{C}$ and washed. The peroxidase activity was measured using o-phenylenediamine (OPD) and hydrogen peroxide as a substrate by spectrophotometry at the wavelength of $492 \mathrm{~nm}$. The resulting OD was plotted against the test sera or IgG dilutions. The antibody titers were referred to either as the "end point" or the U-ELISA amount. The "end point" was generated by the first OD attaining maximal values. The U-ELISA was calculated by using the closest OD to 0.2 . One U-ELISA, defined arbitrarily as the smallest amount of an antibody to yield an OD of 0.2 under the ELISA conditions, was calculated according the following equation [20]:

$$
\mathrm{U}-\mathrm{ELISA}=\{[(\mathrm{DO}-0.200)(\text { Dil. }) / \mathrm{DO}]+\text { Dil. }\} \times 10,
$$

where DO was obtained from the equine antibody dilution closest to 0.200 ; Dil., the IgG (T) dilution corresponding to $\mathrm{DO}$, and 10 refers to per $\mathrm{mL}$ of undiluted antibody. In this work, the antibody quantity in micro- grams was used as a substitute for the antibody dilution to calculate the U-ELISA. All the values were recorded after the appropriate blank correction. Similar assays were used to quantify the anti-BCG antibodies in the purified total immunoglobulin $\mathrm{IgG}$ and the $\operatorname{IgG}_{1}, \operatorname{IgG}_{2 \mathrm{a}}$, $\mathrm{IgG}_{2 \mathrm{~b}}, \mathrm{IgG}_{3}, \mathrm{IgA}$ and $\operatorname{IgM}$ antibody subclasses.

\subsection{Detection of BCG Protein Bands by Western Blotting}

Whole-cell protein extracts from the BCG strain were resolved by SDS-PAGE (15\%) and subsequently transferred onto a nitrocellulose membrane. After transfer, the nitrocellulose sheets were probed with the mouse IgG immunoglobulins isolated from the sera of the BCGimmunized mice, followed by treatment with anti-mouse IgG conjugated to horseradish peroxidase as the secondary antibody. The purified IgG prepared before immunization or from non-immunized mice were used as negative controls. The membranes were developed with a chemiluminescent kit (Millipore) and exposed on an ImageQuant LAS 4000 (GE, USA).

\subsection{BCG Opsonization}

One-hundred microliters of the bacterial suspension were incubated for $30 \mathrm{~min}$ at $37^{\circ} \mathrm{C}$ in $1.0 \mathrm{~mL}$ of phosphate-buffered saline (PBS) with or without the mouse anti-BCG total serum or IgG. One hundred microliters of PBS or serum obtained from non-immunized mice or collected just before immunization were used for opsonization as negative controls. The suspension of opsonized bacteria was centrifuged at $3000 \mathrm{rpm}$ for $10 \mathrm{~min}$ at $4^{\circ} \mathrm{C}$, and the supernatant was discarded. Immediately before the assay, the pellet was suspended in $900 \mu \mathrm{L}$ of warm $\left(37^{\circ} \mathrm{C}\right)$, colorless Hanks' solution (Gibco) buffered to $\mathrm{pH} 7.4$ with $10 \mathrm{mM}$ HEPES, containing $10-5 \mathrm{M}$ luminol (Sigma-Aldrich, St. Louis, MO). All opsonization tests were performed in triplicate.

\subsection{Macrophage Culture, Infection and BCG Phagocytosis}

Murine macrophage-like RAW 264.7 cells (ATCC) were expanded in $25 \mathrm{~cm}^{2}$ or $75 \mathrm{~cm}^{2}$ flasks (Corning) containing DMEM-F12 supplemented with $10 \%$ of BS, at $37^{\circ} \mathrm{C}$ for 5 days. For experiments, the cells $\left(1 \times 10^{6}\right.$ cells $/ \mathrm{mL}$ ) were seeded onto 24 -well plates. The macrophage monolayers were infected with BCG pre-treated with the murine anti-BCG $\operatorname{IgG}$ at a ratio $10 / 1$ bacilli/ macrophage. Samples of BCG incubated with non-immune IgG or PBS were used for infection of the control cultures (always running in parallel). The macrophage/ bacteria interactions were stopped at $1 \mathrm{~h}, 3 \mathrm{~h}, 6 \mathrm{~h}, 9 \mathrm{~h}, 12$ $\mathrm{h}, 24 \mathrm{~h}, 48 \mathrm{~h}$ and $72 \mathrm{~h}$ after infection. The cells were washed with PBS three times to remove any extracellular 
bacteria and examined for phagocytosis of mycobacteria by immunofluorescent microscopy.

\subsection{Immunofluorescence Examination}

The washed cells were fixed with $4 \%$ paraformaldehyde for $15 \mathrm{~min}$ and permeabilized with $0.5 \%$ Triton $\times$ 100 for $30 \mathrm{~min}$ at room temperature. After washing with PBS, the cells were incubated in DMEM-F12 supplemented with $10 \%$ FCS and treated with rabbit antimouse IgG-conjugated with phycoerythrin (1:1000 dilution) for $1.0 \mathrm{~h}$ at $4^{\circ} \mathrm{C}$, in the dark. The cells were covered with ProLong Gold plus DAPI (Invitrogen), and the slide borders were sealed before examination by fluorescence microscopy.

\subsection{Quantification of Intracellular BCG after Phagocytosis by Macrophages}

Macrophages were plated onto 96 -well plates $\left(4 \times 10^{5}\right.$ cells $/ \mathrm{mL}$ ). After adhesion, the cells were infected with BCG bacilli opsonized with immune mouse IgG (100 $\mu \mathrm{g} / \mathrm{ml}$ ) or non-opsonized bacilli at a bacillus:macrophage ratio of $10: 1$ for $15 \mathrm{~min}$ at $37^{\circ} \mathrm{C}$ under constant stirring. The plates were transferred to a $\mathrm{CO}_{2}$ incubator and incubated for different periods of times $(1 \mathrm{~h}, 3 \mathrm{~h}, 6 \mathrm{~h}, 9 \mathrm{~h}, 12$ h, $24 \mathrm{~h}, 48 \mathrm{~h}, 72 \mathrm{~h}$ ). At the indicated intervals, the non-phagocytosed BCG bacilli were removed by three washes with sterile PBS. The bacterial uptake and survival in macrophages was quantified by the CFU test. The infected macrophages were disrupted with $0.1 \%$ saponin, homogenized and serially diluted. After stirring, $60 \mu \mathrm{L}$ samples were plated onto Petri dishes containing 7H10 Middlebrook solid medium. The Petri dishes were incubated for 30 days at $37^{\circ} \mathrm{C}$, and the numbers of $\mathrm{CFU}$ were counted.

\subsection{Quantification of NO Production by Infected Macrophages}

The production of NO was indirectly quantified by measuring the amount of $\mathrm{NO}_{2}-$ in the macrophage supernatants. Fifty microliter samples of the supernatants from each macrophage culture infected with BCG for 24 $\mathrm{h}$ were plated onto 96 wells plates containing $50 \mu \mathrm{l}$ Griess reagent $(1.0 \%$ sulfanilamide, $0.1 \% \mathrm{~N}$-nafitilenediamine and $2.5 \%$ phosphoric acid). After $10 \mathrm{~min}$ of incubation at room temperature, the O.D. was read at 540 $\mathrm{nm}$. The amounts of released NO were calculated by projecting the O.D. obtained onto a previously constructed standard curve based on eight dilutions starting with $200 \mu \mathrm{M} \mathrm{NO}_{2}$.

\subsection{Statistical analysis}

The results were submitted to two-way ANOVA tests using GraphPad Prism 5.0 software (GraphPad, San Diego, CA). A p-value of $<0.05$ was considered indicative of a significant difference.

\section{RESULTS}

\subsection{Production and Purification of the Anti-BCG Antibodies}

Specific anti-BCG antibodies were quantified in the serum of immunized mice by ELISA assay using either rabbit anti-mouse total Immunoglobulin antibody or antibodies specific to different Ig classes (IgG, IgM, IgA, or the subclasses, $\mathrm{Ig}_{\mathrm{G} 1}, \mathrm{IgG}_{2 \mathrm{a}}, \mathrm{IgG}_{2 \mathrm{~b}}$ and $\mathrm{IgG}_{3}$ ). AntiBCG antibodies began to appear after the second immunization $(\mathrm{n}=5$; median $=8.8152 \pm \mathrm{SD}=0.110642)$ compared with the sera collected before immunization (n $=5$; median $=0.20712 \pm \mathrm{SD}=0.079421)$. The titers increased thereafter, reaching 2.54 -fold higher at the $8^{\text {th }}$ booster inoculation with the antigen $(\mathrm{n}=5$; median $=$ $2.0712 \pm 0.116721$ ) (Figure 1). The anti-BCG antibodies were differently distributed among the $\mathrm{IgG}$ subclasses and classes as follows: $\operatorname{IgG}_{1}(\mathrm{n}=3$; median $=1.9983 \pm$ $\mathrm{SD}=0.168197) ; \operatorname{IgG}_{2 \mathrm{a}}(\mathrm{n}=3$; median $=1.467667 \pm 0$, 061744); $\operatorname{IgG}_{2 b}(\mathrm{n}=3$; median $=1.470333 \pm 0.050003)$;

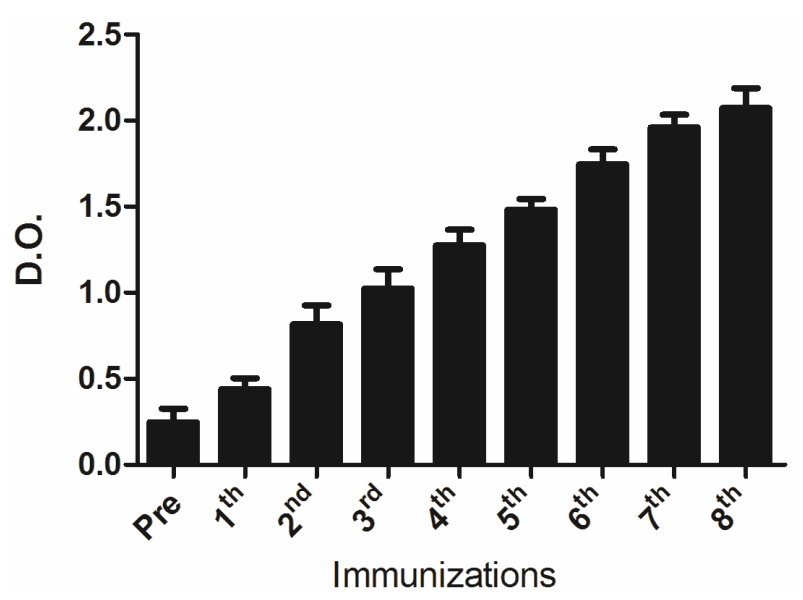

Figure 1. Anti-BCG antibodies were detected in serum of mice immunized with whole BCG. ELISA plate wells were precoated with BCG whole extracts and incubated for $1 \mathrm{~h}$ at $37^{\circ} \mathrm{C}$. After washes and incubation with peroxidase labeled rabbit anti total mouse IgG, the peroxidase activity was measured using o-phenylenediamine (OPD) and hydrogen peroxide as a substrate by spectrophotometry at the wavelength of $492 \mathrm{~nm}$. AntiBCG antibodies started to appear after the second immunization $(\mathrm{n}=5$; median $=8.8152 \pm \mathrm{Sd}=0.110642)$ as compared with sera collected before immunization $(\mathrm{n}=5$; median $=$ $0.20712 \pm \mathrm{SD}=0.079421)$. The titers increased thereafter attaining maximal values after the $8^{\text {th }}$ immunization. The differences among the antibody titers referred to those in sera before and after immunization, and difference between the titers observed after the $2^{\text {nd }}$ and $8^{\text {th }}$ boosters are statistically significant $(p<0.001)$. The assays were performed in triplicates and the results were analyzed by the one way ANOVA test, $\mathrm{p}<0.001$. 
$\operatorname{IgG3}(\mathrm{n}=3 ;$ median $=0.095 \pm 0.001732) ; \operatorname{IgM}(\mathrm{n}=3$; median $=1.30333 \pm 0.060069)$; and $\operatorname{IgA}(\mathrm{n}=3$; median $=1.141 \pm 0.179084$. Anti-BCG antibodies were not detected in the $\operatorname{IgG}_{3}$ fraction or in the serum collected before immunization (Figure 2).

The immunoglobulins were purified by negative caprylic acid precipitation of pooled sera collected from mice immunized with BCG one week after the last booster ( $8^{\text {th }}$ inoculation). The precipitated non-immunoglobulin proteins were removed by centrifugation, and the immunoglobulin-rich supernatant was dialyzed against PBS. The resulting purified immunoglobulin preparation containing $1.0 \mathrm{mg}$ of total protein $/ \mathrm{mL}$ upon analysis by PAGE under reducing conditions manifested the typical immunoglobulin $\mathrm{H}$ and $\mathrm{L}$ chains as the major protein bands (Figure 3).

The anti-BCG antibodies present in these immunoglobulin preparations were quantified by ELISA. Various concentrations of the purified immunoglobulin preparations $(0.78 \mu \mathrm{g}$ to $100 \mu \mathrm{g})$ were added to wells pre-coated with $2 \mu \mathrm{g}$ of whole BCG extract as the primary antibody, and rabbit anti-mouse IgG was added as secondary antibody. Anti-BCG antibodies were significantly detected in a dose-dependent manner even at the lowest doses (Figure 4). As indicated above, the O.D. at $492 \mathrm{~nm}$ corresponding to 0.2 was used to calculate the U-ELISA. This immunoglobulin preparation contained 1794.8 U-ELISA/ $\mathrm{mg}$. This value corresponds to the specific activity of the

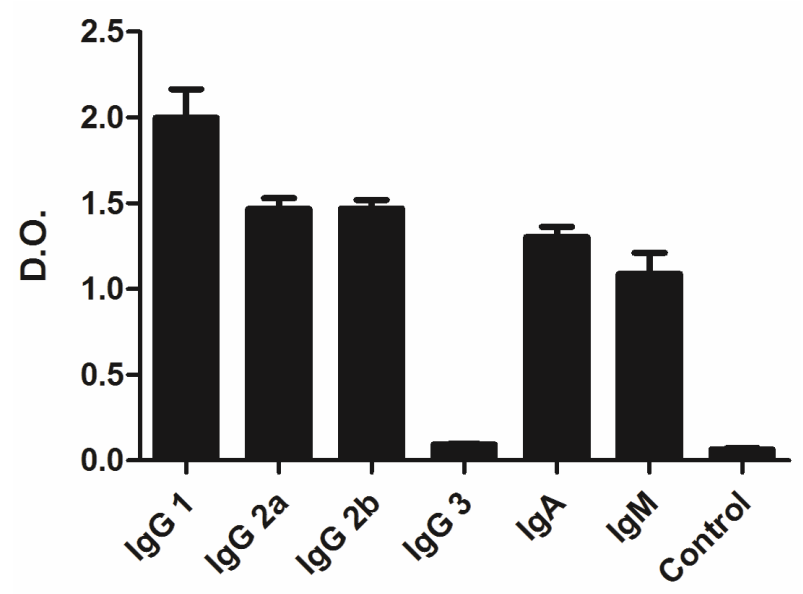

Figure 2. Anti-BCG antibodies were detected in different immunoglobulin classes and subclasses in serum of mice immunized with whole BCG. ELISA plate wells were pre-coated with BCG whole extracts and incubated for $1 \mathrm{~h}$ at $37^{\circ} \mathrm{C}$. After washes and incubation with peroxidase labeled rabbit anti-mouse $\operatorname{IgG}_{1}$, $\mathrm{IgG}_{2 \mathrm{a}}, \mathrm{IgG}_{2 \mathrm{~b}}, \mathrm{IgG}_{3}, \mathrm{IgM}$ and $\mathrm{IgA}$, the peroxidase activity was measured using o-phenylenediamine (OPD) and hydrogen peroxide as a substrate by spectrophotometry at the wavelength of $492 \mathrm{~nm}$. Purified Ig obtained from serum collected just before immunization was always included as negative control. The assays were performed in triplicates and the significance of the results was analyzed by the one-way ANOVA test, $\mathrm{p}<0.001$.

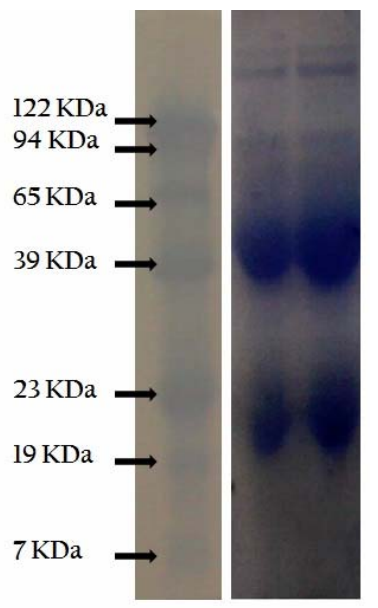

Figure 3. Mice IgG immunoglobulins. Analysis by Western blotting. Total immunoglobulins were purified from pooled sera of BCGimmunized mice by negative precipitation with caprillic acid. Samples of purified immunglobulins were separated by SDS-PAGE, the protein bands were transferred to nitrocellulose membrane and revealed with rabbit anti-mouse Ig antibodies.

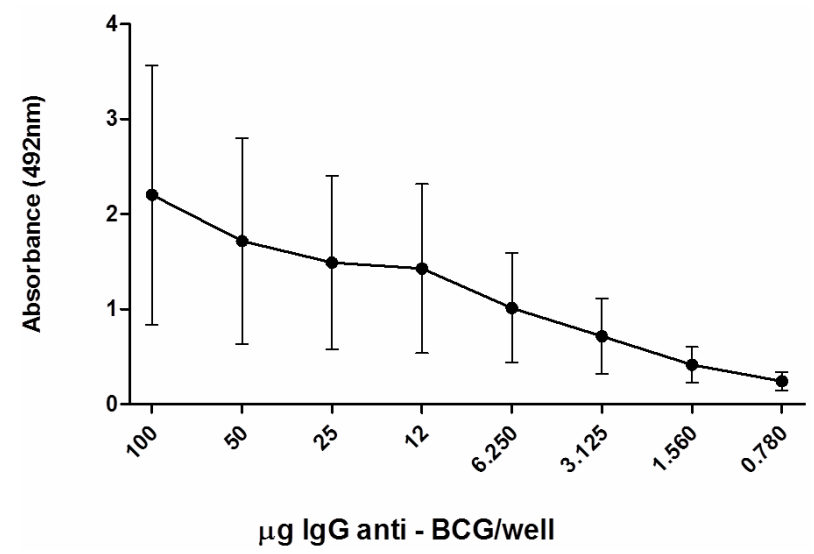

Figure 4. Anti-BCG antibodies are present in purified $\mathrm{IgG}$ immunoglobulins. The anti-BCG antibodies were quantified by ELISA as described for titration in pooled serum from mice sera collected after the $8^{\text {th }}$ immunization using also whole BCG extracts $(1 \mathrm{mg})$ to coat the plates.

purified mouse anti-BCG immunoglobulin preparation. The purified immunoglobulin preparation was capable of recognizing protein bands with different molecular masses ranging from $7 \mathrm{kDa}$ to $122 \mathrm{kDa}$ in whole BCG extracts, as revealed by Western blot analysis. Compatible with the different anti-BCG antibody titers present within the $\mathrm{IgG}$ subclasses, 10 protein bands were clearly detected by $\operatorname{IgG}_{1}$ and 4 by $\operatorname{IgG}_{2 \mathrm{a}}$ and $\operatorname{IgG}_{2 \mathrm{~b}}$, but none were detected with $\mathrm{IgG}_{3}$ (Figure 5). 


\subsection{BCG Opsonization by Anti-BCG Antibodies}

Suspensions of BCG $\left(4 \times 10^{6}\right.$ bacilli per sample $)$ were prepared as indicated in the Materials and Methods, washed with ice-cold PBS and pretreated with the indicated amounts of purified immunoglobulins for $15 \mathrm{~min}$ at $37^{\circ} \mathrm{C}$. After incubation, the bacilli were washed and used for infection of RAW 264.7 cells at a bacteria/macrophage ratio of 10/1. The uptake of the opsonized BCG was examined by immunofluorescence and phase contrast microscopic analyses of the infected macrophages. The results presented in Figures 6(A)-(C) demonstrate the presence of opsonized BCG bacilli inside macrophages. The left panels illustrate stained opsonized bacilli (red) within macrophages (blue nuclei), while the right panels show that the BCG bacilli were also visible inside macrophages by light microscopic examination. The non-opsonized bacilli were detected in macrophages under light microscopy but not by the immunofluorescence test. Figure 6(D) shows macrophage not incubated with BCG.

\subsection{Anti-BCG IgG Modulates Bacilli Phagocytosis by Macrophages}

To determine the effect of the BCG pretreatment with anti-BCG antibodies on phagocytosis, the Raw 264.7 cell monolayers $\left(1 \times 10^{5}\right.$ cells $)$ were infected with opsonized

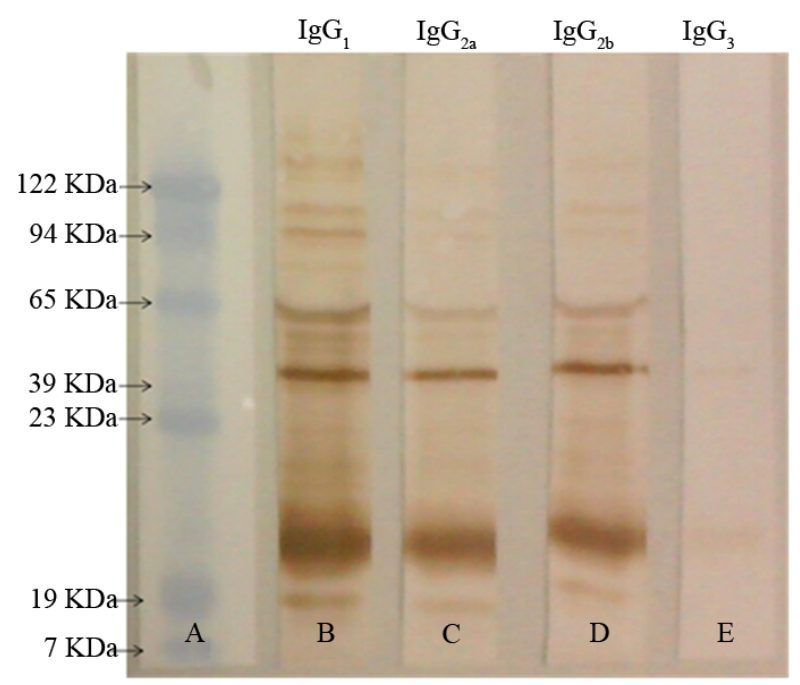

Figure 5. Anti-BCG $\mathrm{IgG}$ antibodies recognize different BCG protein bands. Samples of BCG extracts $(10 \mu \mathrm{g})$ were separated on $12 \%$ polyacrylamide gel electrophoresis and the separated protein bands were transferred to nitrocellulose membranes. Purified mice $\operatorname{IgG}(10 \mu \mathrm{g})$ anti-BCG was used as the first antibody, and monospecific peroxidase labeled IgG anti-mouse $\mathrm{IgG}_{1}, \mathrm{IgG}_{2 \mathrm{a}}$. IgG $\mathrm{Ig}_{2 \mathrm{~b}}$ and $\mathrm{IgG}_{3}$ were used as the secondary antibody. The band detection was accomplished by measuring the peroxidase activity using o-phenylenediamine (OPD) and hydrogen peroxide as a substrate by spectrophotometry at the wavelength of $492 \mathrm{~nm}$.
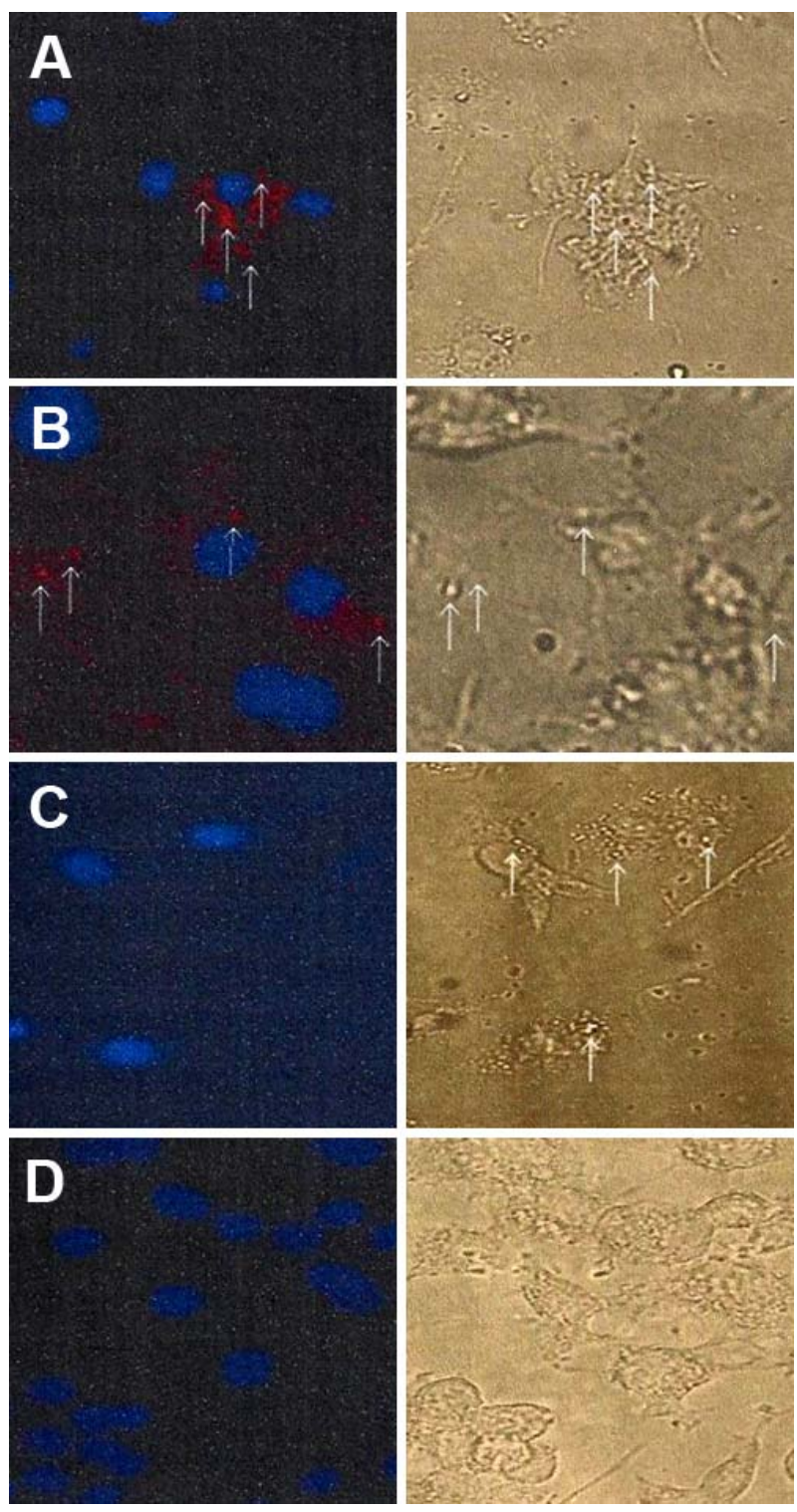

Figure 6. BCG opsonization by anti-BCG antibodies. Raw 264.7 cell monolayers were infected for $3.0 \mathrm{~h}$ at $37^{\circ} \mathrm{C}$ with viable $\mathrm{BCG}$ bacilli, pretreated (A), (B) or not treated (C) with mice anti-BCG antibodies. The bacteria/macrophage ratio was 10/1. After incubation, the cells were washed to remove nonphagocytosed bacilli. The cells were fixed, permebialized, and treated with rabbit anti-mouse IgG-conjugated with phycoeritrin and stained with DNA fluorochrome, DAPI. The resulted cell monolayers were examined using immunofluorescent (A)-(D) or light (E)-(H) microscopy. In Left panel, only the opsonized BCG bacilli (A), (B), but not non-opsonized bacilli (C) were detected inside macrophages with nuclei stained in blue. The opsonized bacilli stained in red are pointed by arrows. In Right panel, the opsonized and non-opsonized intracellular bacilli are pointed by arrows (A)-(D), negative controls; macrophages incubated without BCG bacilli.

or non-opsonized BCG (BCG/macrophage ratio of 10/1) at $37^{\circ} \mathrm{C}$. After different incubation periods, the cell monolayers were washed three times with PBS to re- 
move outside bacilli. The macrophages were disrupted with $0.1 \%$ saponin, and $10 \mu \mathrm{L}$ of the resultant cellular lysate was plated onto Petri dishes containing solid 7H10 culture medium. Next, the plates were incubated for 30 days at $37^{\circ} \mathrm{C}$, and the numbers of CFU were counted. Figure 7(A) shows that the numbers of BCG bacilli recovered from macrophages infected with the opsonized BCG were significantly higher within the first $12 \mathrm{~h}$ of incubation compared with the cells infected with nonopsonized bacilli. The opsonized BCG/non-opsonized BCG phagocytosis ratio, which are greater than 1 until $12 \mathrm{~h}$ of incubation, was inverted after $48 \mathrm{~h}$ of incubation (Figure 7(B)). These results demonstrate that the numbers of intracellular bacteria began to decrease after $24 \mathrm{~h}$ of incubation, suggesting the activation of putative bacterial killing mechanisms in the host macrophages. The observed reduction was more pronounced in the cells infected with opsonized bacilli, suggesting that the bactericidal mechanisms were more potent in these cells.

The putative bacterial killing mechanisms employed

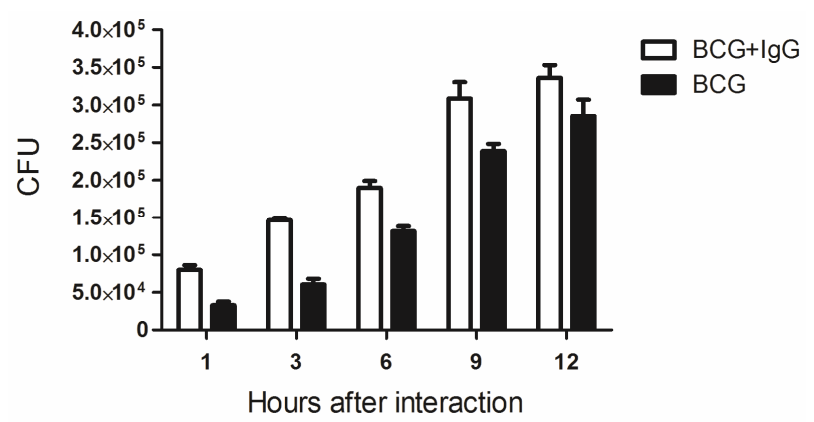

(A)

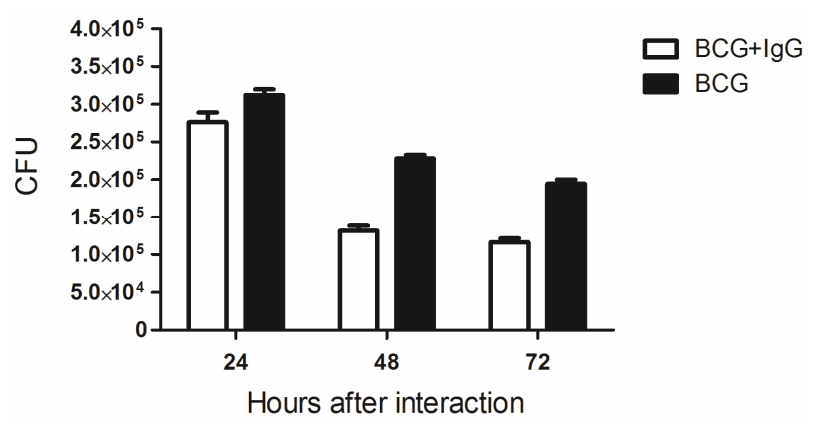

(B)

Figure 7. Potentiation of BCG phagocytosis by pre-opsonization of the bacilli with mice anti-BCG IgG. Adhered Raw 264.7 macrophage cells $\left(4 \times 10^{5}\right.$ cells $/ \mathrm{mL}$ were infected with living BCG bacilli (10:1 bacteria/macrophage) pretreated or not with purified mice anti-BCG. After indicated time of incubation, the cells were washed with PBS and lysed. The obtained lysates were serially diluted, cultivated on solid culture medium, and the resulting CFU was counted. The number of CFU recovered from macrophages incubated with opsonized BCG was significantly higher at the first $12 \mathrm{~h}$ of incubation as compared with the bacilli removal from non-opsonized bacilli (A), declining thereafter (B). by macrophages that phagocytosed the opsonized BCG bacilli were further investigated. To this end, we analyzed the induction of nitric oxide production in macrophages infected with opsonized and non-opsonized BCG. Supernatants from the macrophage cultures were collected, and the NO production was indirectly quantified by determining the amounts of $\mathrm{NO}_{2}$-using Griess reagent (Figure 8(A)) demonstrates that after $24 \mathrm{~h}$ of incubation, NO production increased to reach a maximum at $72 \mathrm{~h}$ of incubation. The production of NO by macrophages phagocytosing opsonized BCG was at least 2-fold higher compared with the non-opsonized bacilli. The ratios of NO production induced in macrophages by the opsonized BCG versus non-opsonized BCG (ratio opsonized/nonopsonized BCG) began to increase after $9 \mathrm{~h}$ of incubation (ratio of 16.6), progressively increasing to reach the highest value at $24 \mathrm{~h}$ (ratio of 6.7), then decreasing until $48 \mathrm{~h}$ (ratio of 1.68) (Figure 8(B)).

\section{DISCUSSION}

The attenuated Mycobacterium bovis (BCG) strain, while retaining the typical characteristics of the species, does not express the relevant components responsible for the original virulence [21]. BCG is an intracellular bacterium that resides within mononuclear phagocytes and preferentially induces a cellular immune response [22]. Accordingly, previous research has largely focused on the activation of $\mathrm{T}$ cell subsets and the resulting cytokine profiles [23-25]. Except for some ancillary approaches, the humoral immune response putatively activated by BCG has been neglected. The exceptions include an analysis of the effects of the BCG growth conditions [15] and different $\mathrm{BCG}$ preparations, such as oral $\mathrm{BCG}$, on the induction of the humoral immune response [16]. The lack of virulence factors and the intrinsic antigenic and adjuvant properties of BCG have long been exploited to protect humans against some forms of tuberculosis $(M$. tuberculosis) and hanseniasis, either through subcutaneous or oral administration. The adjuvant properties of the vaccine qualify BCG to be a vector for virulence factors of other pathogens. Accordingly, reports about the generation of recombinant $\mathrm{BCG}$ expressing virulence factors from Bordetella pertussis or enteropathogenic Escherichia coli have been recently published [16,17]. Detailed investigations of the capacity of BCG to induce humoral immunity are lacking.

The present study was designed to generate data about the pattern of the humoral immune response elicited by BCG in mice, specifically regarding the major qualities of the resulting anti-BCG antibodies. The strategy involved a longer immunization schedule of 7 repetitive boosters following the primary immunization. The implicit objective was to provide ample access of the antigens prevalent in BCG to the different antigen-presenting 


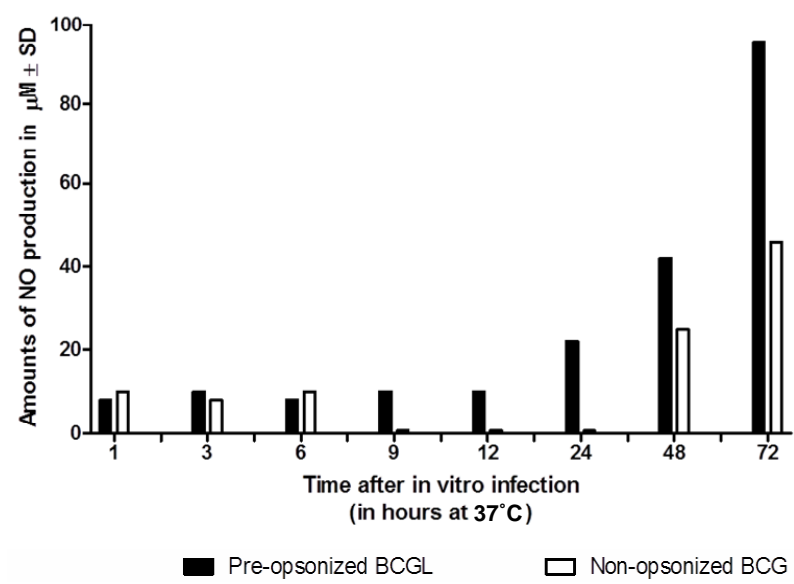

(A)

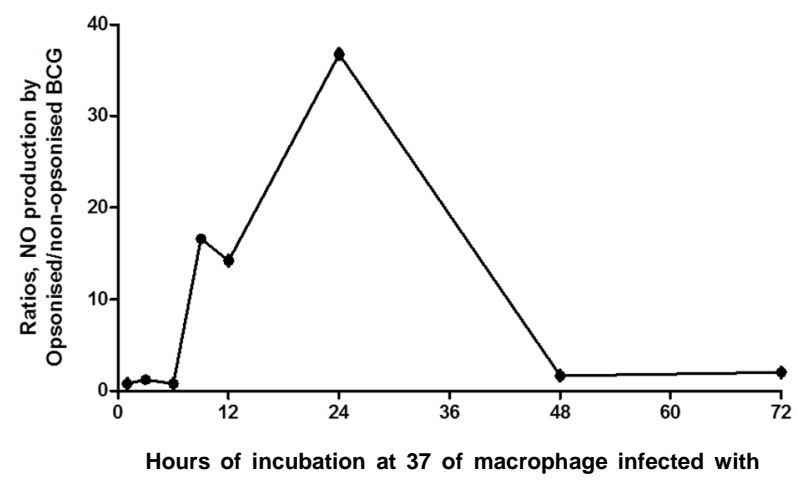

(B)

Figure 8. NO production by Raw 264.7 macrophages infected with BCG. Adhered Raw 264.7 macrophage cells $\left(4 \times 10^{5}\right.$ cells $/ \mathrm{mL}$ ) were infected with living BCG bacilli (10:1 bacteria/macrophage) pretreated (A) or not (B) with purified mice anti-BCG. After indicated time of incubation at $37^{\circ} \mathrm{C}$, the cells were washed with PBS and lysed. The obtained lysates were either used to quantify free NO measured by the amount of $\mathrm{NO}^{2}$-by using the Griess reaction or serially diluted by determining the remaining living BCG bacilli, by cultivation on solid culture medium, and counted the resulting number of resulting CFU. Comparison between the NO production by macrophages infected with BCG bacilli, pre-treated with mice IgG anti-BCG extracts (opsonized), or pre-treated with IgG from non-immunized mice. The basal NO production by macrophages is significantly potentiated after $12 \mathrm{~h}$ of incubation with pre-opsonized BCG bacilli attaining maximal values at 48 $\mathrm{h}$ (A). The recovered ratios of living BCG from macrophages pre-opsonized/non-opsonized ratios were lower after the first hours of incubation ( 0.8 after $1 \mathrm{~h} ; 1.25$ after $3 \mathrm{~h}$, and 0.8 after $6 \mathrm{hrs}$ ), increasing significantly until $24 \mathrm{~h}$ of incubation (ratio of 36.7), declining thereafter (ratio 2.04 after $72 \mathrm{~h}$ of incubation (B). Each point represents media of triplicates.

cells (APC), dendritic cells, macrophages and B cells, leading to the subsequent activation of naïve $\mathrm{T}$ cells, effector $\mathrm{T}$ cells and B cells [26] of anti-BCG antibodies were obtained, as assessed by ELISA (Figure 1). These data indicate that the employed immunization strategy permitted successful MHC class II-dependent presenta- tion of BCG antigens processed by APCs. The resulting consequences of the binding and cross-linking of immunoglobulin receptors, leading to $\mathrm{B}$ cell activation and the upregulation of costimulatory molecules including B7-1, B7-2, and CD40, were apparently achieved. The observed variety of Ig classes and subclasses produced in response to repeated BCG inoculations demonstrated that the expansion and differentiation of $\mathrm{B}$ cell precursors into $\mathrm{Ab}$-secreting plasma cells, immunoglobulin $\mathrm{H}$-chain class and subclasses switching [27] and antibody production occurred (although not investigated in this work). This idea is based on extensively published related data. These events led to anti-BCG antibody production, resulting in high antibody titers and unequal class and subclass distribution (Figure 2). The lowest levels of antiBCG antibodies in the $\mathrm{IgG}_{3}$ subclass may be explained, at least in part, by the known naturally low prevalence of this IgG subclass in the mouse molecular immunoglobulin gene organization [28]. The anti-BCG antibodies of various immunized mouse immunoglobulin classes and subclasses recognized several distinct protein bands from the BCG extracts (Figure 5). Therefore, the protective possibility of the BCG antibodies can at least be double expanded.

Accumulating evidence has implicated both $\operatorname{IgG}$ and IgA antibodies in the host defense against bacterial infections [29]. IgG first interacts with the pathogenic cells or with their soluble components through the Fab-hypervariable regions. The resulting immune complexes formed after the reaction of specific IgGs with the epitopes expressed by the pathogens can activate cell or humoral effector mechanisms.

The effector cell functions of macrophages, monocytes and polymorphonuclear cells are initiated by the interaction of the $\mathrm{IgG} \mathrm{Fc}$ fragments with the $\mathrm{Fc}$ receptors, F $\gamma$ CRI (CD64), F $\gamma$ CRII (CD32), and F $\gamma$ CRIII (CD16), expressed by these cells [30]. The activation of humoral effector mechanisms involves the complement system (CS) as one important source of both anaphylatoxins and $\mathrm{C} 3 \mathrm{~b}$ fragments. The CS can be activated by three pathways: the classical pathway (CP), the MBL pathway (MBLP) and the alternative pathway (AP). The $\mathrm{CP}$ is activated after the interaction of the Fc of immunocomplexes with the $\mathrm{C} 1$ component; the MBLP is initiated by the interaction between mannan-rich bacterial cell components and MAPs; and the AP is initiated after the spontaneous hydrolysis of $\mathrm{C} 3$-thioester bonds and the immediate ligation of exposed $\mathrm{OH}^{-}$or $\mathrm{NH}^{+}$pathogen cell surface components [31]. The activation of these pathways may result in the production of various CS fragments that can combine with specific effector cell-bound receptors, resulting in pathogen destruction. The pathogen killing can be executed by phagocytosis, antibodydependent cell-mediated cytotoxicity, and respiratory 
burst [32].

In this work, we have demonstrated that the anti-BCG antibodies are potentially able to prepare the bacilli for phagocytosis and lysis upon combination with the FcRs of the phagocytes (Figures 6(A)-(D)). The internalization of the opsonized BCG by macrophages during the first hours after infection was significantly higher compared with the non-opsonized BCG (Figure 7(A)). Once inside the phagosomes, the presence of Ig on the BCG cell surface accelerated the bacterial destruction (Figure 7(B)). The observed bactericidal effect was associated with a significant increase in nitric oxide (NO) production (Figure 8(A)). This finding suggests an increase in the production of inducible nitric oxide synthase indicated by a clear inversion of the amounts of BCG recovery from the infected macrophages which was increasing higher until 24h of the macrophage with opsonized BCG (opsonized/non-opsonized BCG ratio of 36.7), then decreasing until $48 \mathrm{~h}$ (ratio of 1.68) (Figure 8(B)). The production of $\mathrm{NO}$, results from the metabolism of arginine to citrulline, and a number of number of enzymes, including nucleoside reductase, resulting in impaired bacterial growth [33-36].

Pathogen-associated patterns (PAMPs) can be recognized extracellularly by germline-encoded pattern-recognition receptors (PRRs) as Toll-like receptors (TLRs) [37], and intracellularly by the cytoplasmic nucleic acid receptors RIG-1 and Mda5 [38,39]. Once inside, cells antibody-coated particles are bound to cytosolic IgG receptor, tripartite motif-containing 21 (TRIM21) [40] via its carboxy (C) terminal PRYSPRY domaim with highest binding affinity [41]. Antibody-coated virus once into the cytoplasm interacts with TRIM21 are degradeted by a process including proteasome [42], ATPase and unfoldase [38]. The TRIM21 activation by intracellular pathogens antibody-bound in TRIM21 sufficient mice, but not in TRIM21 genetically deficient mice [42], results in the production of proinflammatory cytokines, modulation of natural killer stress ligands and induction of an antiviral state [43]. The antibody-mediated killing of BCG phagocytosed by macrophages, besides being attributed to coincidence between reduction of recovered living BCG and NO production can also be related to the TRIM21 proteases activation mediation.

In conclusion, the immunization protocol based on repeated BCG inoculations generates a robust humoral response against antigens expressed by the vaccine strain, leading to high levels of production of different classes and subclasses of specific immunoglobulins. The data obtained justify the use of BCG for the generation of recombinant $\mathrm{BCG}$ vectors expressing genes for virulence factors controlled by antibodies. The opsonizing effect of the induced anti-bacterial antibodies favors the elimination of the immunizing bacteria, preventing the persis- tence of the vaccine strain in the immune organism. The recent demonstration that BCG accepts DNA sequences encoding is important virulence factors from Bordetella pertussis [15] and enteropathogenic Escherichia coli [16] and expresses these factors in the structural and antigenic forms similar to the corresponding natural proteins justifies the use of BCG as a vector. The long-continuing evaluation of the protective anti-Tb effects of BCG justify this vaccine as the remaining available tool to control this infection, particularly in countries with medium or high disease incidence levels [36].

\section{ACKNOWLEDGEMENTS}

The work was supported with research funds from FAPERJPrograma-Cientistas de Nosso Estado (Proc. No.: E-26/100.628/200); FAPESP, (Proc. No.: 09/52804-0); CNPq, Bolsa de Produtividade (WDS), Nível 1A, (Proc. No.: 301836/2005-1). Angela Alice Amadeu and Estevam José Baldon for the kind assistance in the manuscript organization.

\section{REFERENCES}

[1] Calmette, A. (1927) La vaccinacion preventive contre la tuberculose. Masson et Cie, Paris.

[2] Colditz, G.A., Brewer, T.F., Berkey, C.S., Wilson, M.E., Burdick, E., Fineberg, H.V. and Mosteller, F. (1994) Efficacy of BCG vaccine in the prevention of tuberculosis. Meta-analysis of the published literature. JAMA, 271, 698702. doi:10.1001/jama.1994.03510330076038

[3] Fine, P.E., Carneiro, I.A., Milstien, J.B. and Clemens, C.J. (1968) Issues related to the use of BCG in immunization programs: A discussion document. WHO, Geneva, 3-45.

[4] Wilson, M.E., Fineberg, H.V. and Colditz, G.A. (1995) Geographic latitude and the efficacy of bacillus CalmetteGuerin vaccine. Clinical Infectious Diseases, 20, 982-991. doi:10.1093/clinids/20.4.982

[5] Black, G.F., Weir, R.E., Floyd, S., Bliss, L., Warndorff, D.K., Crampin, A.C., Ngwira, B., Sichali, L., Nazareth, B., Blackwell, J.M., Branson, K., Chaguluka, S.D., Donovan, L., Jarman, E., King, E., Fine, P.E. and Dockrell, H.M. (2002) BCG-induced increase in interferon-gamma response to mycobacterial antigens and efficacy of BCG vaccination in Malawi and the UK: Two randomised controlled studies. Lancet, 359, 1393-1401. doi:10.1016/S0140-6736(02)08353-8

[6] Clemens, J.D., Chuong, J.J. and Feinstein, A.R. (1983) The BCG controversy. A methodological and statistical reappraisal. JAMA, 249, 2362-2369. doi:10.1001/jama.1983.03330410048027

[7] Colditz, G.A., Berkey, C.S., Mosteller, F., Brewer, T.F., Wilson, M.E., Burdick, E. and Fineberg, H.V. (1995) The efficacy of bacillus Calmette-Guerin vaccination of newborns and infants in the prevention of tuberculosis: Metaanalyses of the published literature. Pediatrics, 96, 29-35.

[8] Roach, T.I., Barton, C.H., Chatterjee, D. and Blackwell, J.M. (1993) Macrophage activation: Lipoarabinomannan 
from avirulent and virulent strains of Mycobacterium tuberculosis differentially induces the early genes c-fos, $\mathrm{KC}$, $\mathrm{JE}$, and tumor necrosis factor-alpha. Journal of Immunology, 150, 1886-1896.

[9] Freund, J. (1956) The mode of action of immunologic adjuvants. Bibliography Tuberculosis, 10, 130-148.

[10] Zuniga, J., Torres-Garcia, D., Santos-Mendoza, T., Rodriguez-Reyna, T.S., Granados, J. and Yunis, E.J. (2012) Cellular and humoral mechanisms involved in the control of tuberculosis. Clinical and Developmental Immunology, 2012, 1-18. doi:10.1155/2012/193923

[11] Kaufmann, S.H. (1993) Immunity to intracellular bacteria. Annual Review of Immunology, 11, 129-163. doi:10.1146/annurev.iy.11.040193.001021

[12] Collins, H.I. and Kaufmann, S.H. (2002) Acquired imunity against bacteria. In: Kaufmann, S.H., Ed., Immunology of Infectious Diseases, ASM Press, Washington DC, 207-221.

[13] Petricevich, V.L., Ueda, C., Alves, R.C., da Silva, M.A., Moreno, C., Melo, A.R. and Dias da Silva, W. (2001) A single strain of Mycobacterium bovis bacillus CalmetteGuerin (BCG) grown in two different media evokes distinct humoral immune responses in mice. Brazilian Journal of Medical and Biological Research 34, 81-92. doi:S0100-879X2001000100010

[14] Monteiro-Maia, R., Ortigao-de-Sampaio, M.B., Pinho, R.T. and Castello-Branco, L.R. (2006) Modulation of humoral immune response to oral BCG vaccination by $M y$ cobacterium bovis BCG Moreau Rio de Janeiro (RDJ) in healthy adults. Journal of Immune Based Therapies and Vaccines, 4, 4. doi:10.1186/1476-8518-4-4

[15] Nascimento, I.P., Dias, W.O., Mazzantini, R.P., Miyaji, E.N., Gamberini, M., Quintilio, W., Gebara, V.C., Cardoso, D.F., Ho, P.L., Raw, I., Winter, N., Gicquel, B., Rappuoli, R. and Leite, L.C. (2000) Recombinant Mycobacterium bovis BCG expressing pertussis toxin subunit $\mathrm{S} 1$ induces protection against an intracerebral challenge with live Bordetella pertussis in mice. Infection and Immunity, 68, 4877-4883. doi:10.1128/IAI.68.9.4877-4883.2000

[16] Vasconcellos, H.L., Scaramuzzi, K., Nascimento, I.P., Da Costa Ferreira Jr., J.M., Abe, C.M., Piazza, R.M., Kipnis, A. and Dias da Silva, W. (2012) Generation of recombinant bacillus Calmette-Guerin and Mycobacterium smegmatis expressing $\mathrm{BfpA}$ and intimin as vaccine vectors against enteropathogenic Escherichia coli. Vaccine, 30, 5999-6005. doi:10.1016/j.vaccine.2012.05.083

[17] Giles, A.R. (1987) Guidelines for the use of animals in biomedical research. Thrombosis and Haemostasis, 58, 1078-1084.

[18] Remfry, J. (1987) Ethical aspects of animal experimentation. In: Tuffery, A.A., Ed., Laboratory Animals: An Introduction for New Experiments, Intersciences, New York, $5-9$.

[19] Steinbuch, M. and Audran, R. (1969) The isolation of IgG from mammalian sera with the aid of caprylic acid. $A r$ chives of Biochemistry and Biophysics, 134, 279-284. doi:10.1016/0003-9861(69)90285-9

[20] Guidolin, R.G., Marcelino, R.M., Gondo, H.H., Morais,
J.F., Ferreira, R.A., Silva, C.L., Kipnis, T.L., Silva, J.A., Fafetine, J. andDias da Silva, W. (2010) Polyvalent horse $\mathrm{F}\left(\mathrm{Ab} \mathrm{b}^{\prime}\right) 2$ snake antivenom: Development of process to produce polyvalent horse $\mathrm{F}\left(\mathrm{Ab}^{\prime}\right)_{2}$ antibodies anti-african snake venom. African Journal of Biotechnology, 9, 24462455.

[21] Cooper, A.M., Mayer-Barber, K.D. and Sher, A. (2011) Role of innate cytokines in mycobacterial infection. $\mathrm{Mu}$ cosal Immunology, 4, 252-260. doi:10.1016/0003-9861(69)90285-9

[22] Gonzalez-Navajas, J.M., Lee, J., David, M. and Raz, E. (2012) Immunomodulatory functions of type I interferons. Nature Reviews Immunology, 12, 125-135. doi:10.1038/nri3133

[23] Desvignes, L., Wolf, A.J. and Ernst, J.D. (2012) Dynamic roles of type I and type II IFNs in early infection with Mycobacterium tuberculosis. Journal of Immunology, 188, 6205-6215. doi:10.4049/jimmunol.1200255

[24] Kuhn, M., Goebel, W., Philpott, D.J. and Sansonetti, P.J. (2002) Overview of the bacterial pathogens. In: Kaufmann, S.H., Sher, A. and Ahmed, R., Eds., Immunology of Infectious Diseases, ASM Press, Washington, 5-23.

[25] Novikov, A., Cardone, M., Thompson, R., Shenderov, K., Kirschman, K.D., Mayer-Barber, K.D., Myers, T.G., Rabin, R.L., Trinchieri, G., Sher, A. and Feng, C.G. (2011) Mycobacterium tuberculosis triggers host type I IFN signaling to regulate IL-1beta production in human macrophages. Journal of Immunology, 187, 2540-2547. doi:10.4049/jimmunol.1100926

[26] Giacomini, E., Remoli, M.E., Gafa, V., Pardini, M., Fattorini, L. and Coccia, E.M. (2009) IFN-beta improves BCG immunogenicity by acting on DC maturation. Journal of Leukocyte Biology, 85, 462-468. doi:10.1189/jlb.0908583

[27] Zhu, C., Lee, V., Finn, A., Senger, K., Zarrin, A.A., Du Pasquier, L. and Hsu, E. (2012) Origin of immunoglobulin isotype switching. Current Biology, 22, 872-880. doi:10.1016/j.cub.2012.03.060

[28] Vidarsson, G., van Der Pol, W.L., van Den Elsen, J.M., Vile, H., Jansen, M., Duijs, J., Morton, H.C., Boel, E., Daha, M.R., Corthesy, B. and van De Winkel, J.G. (2001) Activity of human IgG and IgA subclasses in immune defense against Neisseria meningitidis serogroup B. Journal of Immunology, 166, 6250-6256.

[29] Ravetch, J.V. and Kinet, J.P. (1991) Fc receptors. Annual Review of Immunology, 9, 457-492. doi:10.1146/annurev.iy.09.040191.002325

[30] Garbett, N.D., Munro, C.S. and Cole, P.J. (1989) Opsonic activity of a new intravenous immunoglobulin preparation: Pentaglobin compared with sandoglobulin. Clinical \& Experimental Immunology, 76, 8-12.

[31] Armstrong, J.A. and Hart, P.D. (1971) Response of cultured macrophages to Mycobacterium tuberculosis, with observations on fusion of lysosomes with phagosomes. Journal of Experimental Medicine, 134, 713-740. doi:10.1084/jem.134.3.713

[32] Deretic, V. and Fratti, R.A. (1999) Mycobacterium tuberculosis phagosome. Molecular Microbiology, 31, 16031609. doi:10.1046/j.1365-2958.1999.01279.x

[33] Shiloh, M.U., MacMicking, J.D., Nicholson, S., Brause, 
J.E., Potter, S., Marino, M., Fang, F., Dinauer, M. and Nathan, C. (1999) Phenotype of mice and macrophages deficient in both phagocyte oxidase and inducible nitric oxide synthase. Immunity, 10, 29-38. doi:S1074-7613(00)80004-7

[34] Encinales, L., Zuniga, J., Granados-Montiel, J., Yunis, M., Granados, J., Almeciga, I., Clavijo, O., Awad, C., Collazos, V., Vargas-Rojas, M.I., Banales-Mendez, J.L., VazquezCastaneda, L., Stern, J.N., Romero, V., Fridkis-Hareli, M., Terreros, D., Fernandez-Vina, M. and Yunis, E.J. (2010) Humoral immunity in tuberculin skin test anergy and its role in high-risk persons exposed to active tuberculosis. Molecular Immunology, 47, 1066-1073. doi:10.1016/j.molimm.2009.11.005

[35] Nathan, C. (1997) Inducible nitric oxide synthase: What difference does it make? Journal of Clinical Investigation, 100, 2417-2423. doi:10.1172/JCI119782

[36] Pereira, S.M., Dantas, O.M., Ximenes, R. and Barreto, M.L. (2007) BCG vaccine against tuberculosis: Its protective effect and vaccination policies. Revista de Saúde Pública, 41, 59-66.

[37] Akira, S. and Takeda, K. (2004) Toll-like receptor signalling. Nature Reviews Immunology, 4, 499-511.

[38] Yoneyama, M., Kikuchi, M., Natsukawa, T., Shinobu, N., Imaizumi, T., Miyagishi, M., Taira, K., Akira, S. and Fujita, T. (2004) The RNA helicase RIG-I has an essential function in double-stranded RNA-induced innate antiviral responses. Nature Immunology, 5, 730-737.

[39] Matzinger, P. (1994) Tolerance, danger, and the extended family. Annual Review of Immunology, 12, 991-1045. doi:10.1146/annurev.iy.12.040194.005015

[40] Mallery, D.L., McEwan, W.A., Bidgood, S.R., Towers, G.J., Johnson, C.M. and James, L.C. (2010) Antibodies mediate intracellular immunity through tripartite motifcontaining 21 (TRIM21). Proceedings of the National Academy of Sciences of the Untied States of America, 107, 19985-19990. doi:10.1073/pnas.1014074107

[41] James, L.C., Keeble, A.H., Khan, Z., Rhodes, D.A. and Trowsdale, J. (2007) Structural basis for PRYSPRY-mediated tripartite motif (TRIM) protein function. Proceedings of the National Academy of Sciences of the Untied States of America, 104, 6200-6205. doi:10.1073/pnas.0609174104

[42] Hauler, F., Mallery, D.L., McEwan, W.A., Bidgood, S.R. and James, L.C. (2012) AAA ATPase p97/VCP is essential for TRIM21-mediated virus neutralization. Proceedings of the National Academy of Sciences of the Untied States of America, 109, 19733-19738. doi:10.1073/pnas.1210659109

[43] McEwan, W.A., Tam, J.C., Watkinson, R.E., Bidgood, S.R., Mallery, D.L. and James, L.C. (2013) Intracellular antibody-bound pathogens stimulate immune signaling via the Fc receptor TRIM21. Nature Immunology, 14, 327-336. 